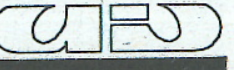

no. $28,29 / 1995$

Tine STANOVNIK

\title{
Nekaj ekonomskih problemov v zvezi s stanovanji v Sloveniji
}

\section{The Economics of Housing; some relevant issues in Slovenia}

Stanovanja Ștanovanjska politika Reforme Slovenija

Podan je kratek prikaz stanovanjske politike na Slovenskem ter najpomembnejši problemi, ki so danes prisotni na stanovanjskem področju. Zagovarjamo tezo, da je osnovna naloga stanovanjskege politike razvoj neprofitnega najemnega sektorja.

Housing Housing policy Reforms Slovenia

A brief overview of the past housing policy in Slovenia is given, together with the most pressing problems facing the housing sector. Arguments in favour of the development of an economically and financially viable non-profit rental sector are presented.

\section{Uvod}

Stanovanjsko področje pomeni nekakšno križišče, v katerem se stikajo, prepletajo in srečujejo posamezne "podzvrsti" socialne, ekonomske in družinske politike, če seznam omejimo le na tiste vrste politike, ki so pomembne za družboslovne raziskave. Stanovanjske politike torej ni moč analizirati in vrednotiti, ne da bi upoštevali širše družbene razmere. $V$ tem smislu se na stanovanjskem področju zrcalijo uspehi in neuspehi nacionalne ekonomske, socialne in družinske politike. Mogoče bi lahko celo uporabili izrek: Povej mi, kako imaš urejeno stanovanjsko področje, in povem ti, kdo si!

\section{Introduction}

Housing represents a kind of a junction, with the intercrossing and merging of various forms of social policy, economic policy and family policy. In this respect housing policy cannot be properly analysed without taking into account the social and economic context in which such a policy is formulated. It might even be said that housing policy reflects the successes and failures of national economic, social and family policies.

Our aim in this short paper is to briefly present developments in the housing sector in Slovenia in the recent past and show how housing policy was dependent on "broader" developments - particularly regarding changes in the economic policy and changes in the socio-economic system. Finally, we present a discussion of some issues relevant for the formulation of a national housing policy.

\section{Housing in Slovenia in the 80 s and 90 s}

\section{Osnovne ekonomske determinante stanovanjskega področja $v 80$. in 90 . letih}

Za stanovanjsko področje v Sloveniji je bil do srede osemdesetih let značilen močan intervencionizem. Izpuščamo atribut "državni", ker bi bil verjetno izraz "samoupravni intervencioniżem" bolj primeren. Druž-
Housing in Slovenia was - up to the mid-eighties - characterized by strong interventionism. We omit the attribute "state", since this interventionism was, unlike most communist countries, based on the concept of self-managed and social ownership. The social ownership in the housing sector and also -to a large degree- private ownership, we- 
bena lastnina na stanovanjskem področju in $v$ pomembni meri tudi zasebna lastnina se je "razvijala in širila" predvsem z različnimi oblikami prisilne akumulacije, ki je zavzemala naslednje oblike:

a) Prispevki na bruto plače in dodeljevanje sredstev na osnovi samoupravno sprejete odločitve o delitvi sredstev za stanovanjski sklad po zaključnem računu. S prispevki na bruto plače se je financiral t.i. "solidarnostni sklad"; reševanje stanovanjskih problemov zaposlenih pa so omogočala izločena sredstva po zaključnem računu in del obveznih prispevkov (ki je ostal v podjetju). iz teh sredstev so $v$ podjetjih kupovali stanovanja na "trgu" in/ali zaposlenim dajali ugodna posojila za gradnjo ali nakup stanovanja.

b) Posojila, ki so jih dajala podjetja so bila "oplemenitena" $z$ bančnimi posojili. To "plemenitenje" oziroma multipliciranje sredstev niso omogočala samo sredstva, ki so jih podjetja deponirala v bankah, temveč tudi sredstva, ki so jih zaposleni privarčevali za nakup ali gradnjo stanovanja, tj: bančni depoziti varčevalcev. Glede na to, da je bila obrestna mera za posojila dolgo realno negativna, oziroma ni bila vezana na stopnjo inflacije, takšna oblika financiranja ne pomeni nič drugega koł transfer premoženja, ki je v premo(enjski bilanci bank povzročil velike "črne luknje".

Po letu 1987 so bile obrestne mere odvisne od stopnje inflacije (po formuli $R+r$ ), leta 1989 pa je bil dokončno odpravljen prispevni sistem za stanovanjsko gradnjo. Uvedbo realnih pozitivnih obrestnih mer je treba gledati $v$ širšem smislu sprememb $v$ ekonomski politiki tedanjega časa, ko se je Mikulićeva vlada po mnogih letih omahovanja le odločila za tržnejše vrednotenja produkcijskega faktorja - kapitala. Danes se verjetno le malokdo spominja, da je ta sprememba posredno povzročila rast cen (inflacijo) in dolge razprave o "kokoši in jajcu". Kasnejšo ukinitev sistema prispevkov (v letu 1989) je prav tako treba gledati $v$ širšem smislu - tokrat $v$ re being developed through various forms of forced accumulation, i.e. explicit and implicit subsidies, either to the demand side or supply side. These were as follows:

a) Levies on gross wages and part of retained firm profits. These levies were for the financing of the socalled "solidarity housing fund" of a municipality, with the levy being set by the self-managed housing association in a given municipality. Part of the levy was retained by the firm; this part, together with retained profits (earmarked for housing) was the amount available for solving the housing problems of firm employees. Out of these funds the firm could

a1. buy new apartments, which the firm employees could rent. Formally, these apartments were not firm ownership but rather social ownership.

a2. provide favourable housing loans to its employees for the purchase or construction of a dwelling.

b) Loans, offered by firms could be augmented by banking loans. This was possible by depositing the firms housing funds in a given bank, as well as by savings deposits by employees. The twin source of housing finance (deposited firm loans and savings deposits) produced a suitable multiplicative effect. Since the interest rate was - up to the mideighties- negative in real terms, this kind of financing was in effect a massive transfer of wealth, with the balance sheets of the banks paying the final price. It thus comes as no surprise that the banks in Slovenia are in a large restructuring process!

From 1987 the interest rates were tied to the inflation rate, and in 1989 the whole housing finance system was dismantled. Both events must be viewed in the wider context of changes in the economic policy and broader systemic change. The introduction of real interest rates, preceded by long discussions on the pros and cons, marked the beginning of serious economic reform in 
okviru "demontaže" sistema samoupravnega socializma. $V$ tem smislu izkušnje $\vee$ Sloveniji potrjujejo našo trditev, da dogajanj na stanovanjskem področju praviloma ne moremo analizirati, ne da bi upoštevali tudi spremembe $v$ relevantni socialni in ekonomski politiki, ali celo relevantnih makroekonomskih okoliščin. V tabeli 1 vidimo, da so imele opisane spremembe povsem konkretne posledice, predvsem pa so prizadele stanovanjsko gradnjo v družbenem sektorju (sedaj ga imenujemo "investitor - pravna oseba).

Zasebni sektor (sedaj imenovan "investitor - fizična oseba) je - kot je razvidno iz tabele - pokazal bistveno večjo odpornost, ker je očitno tudi precej manj odvisen od "zunanjega" financiranja oziroma "zunanjih" razmer. Ob izjemno skromnem povečanju stanovanjskega fonda $v$ obdobju tranzicije pa ne moremo mimo dejstva, da se je kvaliteta

Tabela 1: Dokončana stanovanja v Sloveniji glede na tip investitorja, 1980-1994

\begin{tabular}{|c|c|c|c|}
\hline Leto/Year & Skupaj / Total & $\begin{array}{c}\text { Individualni } \\
\text { investitorji / } \\
\text { Individual investors }\end{array}$ & $\begin{array}{c}\text { Investitorji Pravne } \\
\text { osebe / Investors } \\
\text { Legal persons }\end{array}$ \\
\hline \hline 1980 & 13.672 & 6.673 & 6.999 \\
\hline 1981 & 14.674 & 6.393 & 8.281 \\
\hline 1982 & 13.245 & 6.140 & 7.105 \\
\hline 1983 & 12.344 & 6.710 & 5.634 \\
\hline 1984 & 11.612 & 6.702 & 4.910 \\
\hline 1985 & 11.252 & 7.138 & 5.114 \\
\hline 1986 & 12.937 & 8.050 & 4.887 \\
\hline 1987 & 10.212 & 6.249 & 3.963 \\
\hline 1988 & 9.799 & 6.115 & 3.684 \\
\hline 1989 & 8.541 & 6.281 & 2.260 \\
\hline 1990 & 7.759 & 5.513 & 2.246 \\
\hline 1991 & 5.918 & 4.586 & 1.332 \\
\hline 1992 & 6.492 & 5.143 & 1.349 \\
\hline 1993 & 7.846 & 7.052 & 794 \\
\hline 1994 & 5.522 & 4.984 & 538 \\
\hline
\end{tabular}

Vir: Statistični letopis Slovenije 1993, Statistične informacije 163/1994 in 258/1995

Opomba: velik porast $v$ številu dokončanih stanovanj pri individualnih investitorijh v letu 1993 je posledica večletnega zaostanka pri poročanju iz občine Koper. Ta zaostanek so nadoknadili leta 1993, ko so za občino Koper prijavili kar 2007 dokončanih stanovanj pri individualnih investitoriih.
Yugoslavia. The dismantling of the contributory system for housing finance in 1989 also has to be observed in its wider context - i.e. as an important measure in the demolition of the socialist self-managed system, with housing being one of the first casualties.

In this sense the experience of Slovenia shows that the changes in the housing sector are - to a dominant degree - determined by broader socio-economic considerations. From table 1 we observe that both changes (in 1987 and 1989) strongly affected the housing sector, particularly via housing construction. Obviously, the hardest hit was the social sector (now named "investorlegal person").

The private sector (now named "individual investor") has shown considerable resilience to changes in financial conditions. This is in no

Table 1: Apartments completed in Slovenia, as regards the type of investor, 1980-1994

Source: Statistical Annual of Slovenia 1993, Statistical information 163/1994 and 258/ 1995

Note: The large increase in number of completed dwellings in 1993 is due to the unreporting of Koper municipality in previous years. This backlog was cleared in 1993 when the municipality of Koper reported 2007 completed dwellings by individual investors. 
tega fonda v preteklih letih nenehno izboljševala, kar je razvidno iz łabele 2 .

Oktobra 1991 je bil v skupščini Republike Slovenije sprejet nov stanovanjski zakon, ki naj bi postavil temelje za novo ureditev stanovanjskega področja. Naloga je bila seveda zastavljena nekoliko preveč velikopotezno. Z zakonom sta bili inavgurirani dve pomembni in ireverzibilni spremembi:

a) Odprodaja oziroma privatizacija družbenega stanovanjskega fonda

Z odprodajo stanovanj naj bi "z enim nonšalantnim zamahom" odpravili družbeno lastnino na stanovanjskem področju. To se je dejansko tudi zgodilo, tako da je družbeni fond, imenovan "neprofitni najemni fond", sedaj povsem na obrobju ne samo kvantitativno, temveč tudi kvalitativno. Posledice $v$ kvalitativnem smislu so bile predvsem $v$ dejlitetnejši del družbenega stanovanjskega fonda; analiza privatizacije je podrobno prikazana $\mathrm{v}$ raziskavi $\mathrm{T}$. Stanovnika (1994). $V$ tabeli 3 je podanih nekaj osnovnih značilnosti stanovanjskega standarda za tri skupine gospodinjstev:

1. gospodinjstva, ki so odkupila stanovanje na osnovi stanovanjskega zakona (bodisi $v$ enkratnem znesku bodisi obročno);

2. gospodinjstva, ki niso odkupila stanovanja, a so imela to možnost;

3. vsa gospodinjstva $\vee$ Sloveniji.

Tabela 2: Opremljenost stanovanja $z$ instalacijami (v \%), 1988 in 1993 stvu, da je bil odkupljen le kva-

small part due to the fairly large reliance on non-market forms of provision, i.e. community help, family loans etc.

While, on the one hand, we observe a large decrease in the number of completed dwellings, on the other hand the quality of the existing dwelling stock has been continually enhanced, as can be seen from table 2.

Following the 1989 changes, which gave a mortal blow to housing finance, but in essence left the existing social sector intact, the 1991 Housing act provided the legal frame for the complete transformation of the housing sector. Like so many grand schemes, characterized by comprehensiveness, only some propositions have been implemented to the full. The more important are:

\section{a) The privatisation of the social housing stock}

Social housing, which comprised some $35 \%$ of the total housing stock was offered for sale to the sitting tenants. Virtually no part of this large stock was exempt, and very large discounts were offered. Thus the first post-socialist government made to the public "an offer you could not refuse". The details of the privatisation sale are presented elsewhere (Stanovnik 1994);-we observe here that the results were quite predictable, with the best part of the social housing stock sold to sitting tenants. A post festum (or perhaps post mortem?) of the pri-

Table 2: Equipment of apartment with installations (in \%), 1988 and 1993

\begin{tabular}{|l|c|c|}
\hline & 1988 & 1993 \\
\hline \hline centralno ogrevanje/central heating & 61.5 & 70.9 \\
\hline plinska napeljava/gas main & 9.7 & 11.6 \\
\hline telefon/telephone & 49.3 & 68.2 \\
\hline $\begin{array}{l}\text { skupna TV antena ali kabelski priključek/ } \\
\text { joint TV aerial or cable connection }\end{array}$ & 38.9 & 59.9 \\
\hline površina stanovanja $\left(\mathrm{v} \mathrm{m}^{2}\right)$ /size of apartment (in sq $\mathrm{m}$ ) & 75.2 & 76.1 \\
\hline
\end{tabular}

Vir: Ankete o porabi v gospodinjstvih v letih Source: Household Expenditure Surveys in 1988 in 1993, Urad RS za statistiko.
Years 1988 and 1993 . Statistical Office of Slovenia 
Podatki v tabeli 3 so zelo zgovorni: stanovanja, ki so bila odkupljena, so bila kvalitetnejša od stanovanj, ki v stanovanjskem fondu niso bila odkupljena. Po opremljenosti so odkupljena stanovanja presegala tudi kvaliteto opremljenosti celotnega stanovanjskega fonda. Tako je npr. $79.3 \%$ odkupljenih stanovanj imelo centralno ogrevanje (daljinsko, blokovno ali etažno), pri neodkupljenih stanovanjih je imelo centralno ogrevanje le $61.7 \%$ stanovanj, kar je nižje od nacionalnega povprečja ( $V$ Sloveniji ima centralno ogrevanje $70.9 \%$ vseh stanovanj).

\section{b) Ustanovitev Stanovanjskega} sklada Republike Slovenije

Stanovanjski zakon iz leta 1991 je za Stanovanjski sklad Republike Slovenije (SSRS) predvidel pivotalno mesto; skrbel naj bi za financiranje nacionalnega stanovanjskega programa, spodbujal pa naj bi tudi stanovanjsko gradnjo, prenovo in vzdrževanje stanovanj (člen 79). Sklad naj bi dejansko nadomestil delovanje prejšnjih državnih in pacij. Intervencionizem sklada naj bi se izražal predvsem s financiranjem oziroma kreditiranjem po ugodni obrestni meri. Kapitalska osnova sklada naj bi se formirala: a) na osnovizakonsko določenega deleža iz zbranih kupnin (20\% kupnine družbenega stanovanjskega fonda.

Tabela 3: Stanovanjski standard in socioekonomske značilnosti za tri skupine gospodinjstev, leto 1993 radržavnih (samoupravnih) institu-

vatisation bonanza is presented in table 3 , which shows the housing standard for three types of households:

1.households which purchased their apartment through the provisions of the Housing act;

2. households which did not purchase their apartments, but had the opportunity to do so;

3. all households in Slovenia

The data presented in table 3 speak for themselves. The housing (and household income) characteristics of group 1 are "top of the class"; the quality of the purchased dwellings by far surpasses the quality of the unpurchased part as well as the quality of the total housing stock.

The unsold part of the social housing stock was relegated to the nonprofit rental sector; this sector though defined and instituted in the Housing act - is in fact still in its infant stage, with unsufficient economic and financial backing. This is of course due to the fact that the worst and "unsaleable" part of the social housing stock landed in its lap.

Be what may, due to the Housing act the housing ownership structure has changed dramatically. From 1988 to 1993 , the share of owner-occupied apartments increased from $11 \%$ to $30 \%$, owner-occupied houses from $53 \%$ to $57 \%$

Table 3: Housing standard and social-economic characteristics for three groups of household, year 1993

\begin{tabular}{|c|c|c|c|}
\hline - & $\begin{array}{c}\text { Skupina } 1 \text { i } \\
\text { Group } 1\end{array}$ & $\begin{array}{c}\text { Skupina } 2 / \\
\text { Group } 2\end{array}$ & $\begin{array}{c}\text { Skupina } 3 \text { / } \\
\text { Group } 3\end{array}$ \\
\hline $\begin{array}{l}\text { gospodinjstvo ima:/household has: } \\
\text { - centralno ogrevanje/central heating } \\
\text { - plinsko napeljavo/gas main } \\
\text { - telefon/telephone }\end{array}$ & $\begin{array}{l}79.3 \% \\
24.5 \% \\
76.5 \%\end{array}$ & $\begin{array}{l}61.7 \% \\
11.1 \% \\
42.4 \% \\
\end{array}$ & $\begin{array}{l}70.9 \% \\
11.6 \% \\
68.2 \%\end{array}$ \\
\hline $\begin{array}{l}\text { starost stanovanja ( } v \text { letih)/ } \\
\text { age of apartment (in years) }\end{array}$ & 25.9 & 36.4 & 34.5 \\
\hline $\begin{array}{l}\text { število članov gospodinjstval } \\
\text { number of household members }\end{array}$ & 2.9 & 2.5 & 3.0 \\
\hline $\begin{array}{l}\text { povprečna površina stanovanja }\left(\mathrm{v} \mathrm{m}^{2}\right) / \\
\text { average size of apartment (in } \mathrm{sq} \mathrm{m} \text { ) }\end{array}$ & 57.5 & 48.9 & 76.1 \\
\hline $\begin{array}{l}\text { letni denarni dohodek v družini ( } \mathrm{v} \text { tisočih } \\
\text { tolarjev)/ } \\
\text { annual family income (in thoușand SIT) }\end{array}$ & 1307.3 & 796.0 & 1218.2 \\
\hline
\end{tabular}

Vir: Anketa o porabi v gospodinjstvih v letu 1993, Zavod Republike Slovenije za statisSource: 1993 Household Expenditure Survey, Statistical Office of Slovenia 
ki je bil v lasti podjetij in občin) in b) iz subvencij iz državnega proračuna. Hitro - to je bilo tudi predvidlijvo - se je pokazalo, da je kapitalska osnova, formirana iz deleža kupnin, prešibka za izrazițejšo obliko intervencionizma na tem področju. Razpisi za posojila pod ugodnimi pogoji $(R+3)$ so bili večinoma omejeni na individualne prosilce, predvsem za gradnje ali nakup stanovanj. To je nekoliko presenetlijvo, če upoštevamo, da ima Slovenija - zaradi množične stanovanjske privatizacije - izjemno velik lastninski fond in da bi zaradi tega morali povečati najemni fond. S tem bi se struktura lastništva bolj uravnovesila in ustvarjene bi bile okoliščine za boljšo prostorsko in socialno mobilnost. Seveda lahko rečemo, da sklad uresničuje svojo "lastno" kreditno politiko, ker ni izoblikovane neke "družbene" politike; na tem področju pa tudi niso določene "družbeǹe" prioritete. Kakorkoli že, zaradi hi-trega "presuševanja" kapitalske osnove sklada je-bilo iz državnega proračuna $v$ letu 1995 nakazanih 2,5 milijard tolarjev (kot subvencija skladu), v letu 1996 pa je predvidenih 1,5 milijard tolarjev. Niti najmanjšega dvoma ni, da je $v$ primerjavi z drugimi evropskimi državami, takšen obseg državnega intervencionizma zelo skromen.

\section{Ekonomski pogled na stanovanjsko področje}

Iz tega kratkega prikaza je razvidno, da je stanovanjsko področje trenutno nekoliko zapostavljeno, kar pomeni, da je $v$ primerjavi $z$ drugimi družbenimi prioritetami nižje na lestvici, vsaj takrat, kadar so te prioritete ex post določene na osnovi alokacije sredstev iz blagajn javnih financ (tj. iz državnega proračuna). $\mathrm{Ne}$ moremo reči, da je nizko "uvrščanje" stanovanjskega področja na lestvici družbenih prioritet nekaj, kar bi bilo že vnaprej slabo. Zakaj? Tudi Lundquist (1990: 3) namreč dobro ugotavlja, "da na stanovanjski trg lahko gledamo kot na sistem, kí ga označuje staini proces medsebojnega prilagajanja gospodinjstev in stanovanj-predvsem skozi stalno interakcijo med ponud- and the share of the rental sector (private or social) decreased from $36 \%$ to $13 \%$.

\section{b) The National Housing Fund}

The Housing act of 1991 also contained provisions regarding the formation of the National Housing Fund (NHF). It was anticipated that this institution would be instrumental in fostering long-term change in the housing sector. The functions of the National Housing Fund were primarily in the field of housing finance and it was also hoped that a National Housing Policy would be pursued through a welldefined credit policy by the Fund.

Thus the prime task and mean of intervention of the National Housing Fund was to be through granting loans under favourable conditions (i.e. below-market interest rate). The initial capital of the Fund was formed mainly from the legally earmarked proceeds from the sale of the social housing stock ( $20 \%$ of the sales price). This capital was clearly insufficient for more substantial intervention in the housing field. The 1995 and 1996 State budgets provided a much needed but still fairly weak injections (some 2.5 billion tolars and 1.5 billion tolars respectively).

Disbursed loans were mostly for private applicants (for purchase or construction of dwelling). This is somewhat surprising, in view of the fact that owner-occupied dwellings in Slovenia already represent an "indecent" share in the total housing stock. Such a policy cannot but create even greater disbalances and prove to be a serious obstacle for the imperative increase in social and geographical mobility.

While the NHF is formally governed by the supervisory Board of Directors, appointed by the Government of Slovenia, one could pose the question: how "autonomous" ought the NHF be. Can the NHF formulate and pursue-its own credit policy, or must it pursue a credit policy within well defined boundaries and constraints set by other, perhaps more representative (and democratically elected) bodies. 
bo (tj. produkcijo) in povpraševanjem. Rezultat tega procesa variira med dvema ekstremoma: med načelom "primerno stanovanje vsakemu glede na potrebe" in načelom "stanovanje na osnovi efektivnega povpraševanja".

Verjetno ni ekonomista, ki bi trdil, da je za stanovanjsko področje edino relevantno načelo efektivnega (tj. denarno podprtega) povpraševanja. Prav tako pa tudi ni ekonomista, ki bi zagovarjal tezo, da je za stanovanjsko področje edino relevantno načelo "primerno stanovanje vsakemu glede na njegove potrebe". Državni intervencionizem - ki omogoča odmik od merila efektivnega povpraševanja - opravičuje teorija: stanovanje spada $v$ kaìgorijo dobrin s posebnim družbenim pomenom, "poraba" te dobrine pa ustvarja pozitivne zunanje učinke; zaradi tega je efektivno privatno povpraševanje po tej dobrini manjše od "družbenega". Skratka, če državni intervencionizem opravičuje teorija, pa seveda ne moremo nič reči o obsegu tega intervencionizma, kajti tudi neekonomistom je jasno, da je skrajna oblika tega intervencionizma, tj. "vsakemu po potrebah" komunistično geslo ali pobožna želja. Ekonomija je veda o optimalni alokaciji omejenih sredstev; zavedati se moramo, da imamo tudi v skupini dobrin s posebnim družbenim pomenom, za katero je značilen ne povsem tržni sistem alokacije (†j. neupoštevanje načela efektivnega povpraševanja kot edinega merila alokacije) različne dejavnosti - šolstvo, zdravstvo itd. -, ki si prav tako "prizadevajo" za omejena razpoložljiva sredstva. "Oskrbe" s stanovanji zato nikakor ne moremo ločiti od oskrbe $z$ ostalimi dobrinami, ki so posebnega družbenega pomena; res pa je, da je od razpoložljive zmogljivosti družbe in tipa države blaginje precej odvisna kvaliteta in kvantiteta teh dejavnosti.

Ta - ekonomski - pogled na stanovanjsko področje je za. Slovenijo še kako pomemben. Če zagovarjamo tezo, da je zaradi upada stanovanjske gradnje $\vee 90$. letih prišlo do povečane neskladnosti med stanovanjskimi potrebami in razpoložlijvo oskrbo, lahko zagovarjamo tudi
In effect, one can say that the Government has simply pulled out of the housing sector, relegated interventionism to the newly formed NHF, but without providing the financial means and social guidelines which are necessary for a meaningful intervention.

\section{An Economic Overview of the Housing Sector}

There is no doubt that the housing sector is currently quite low on the list of Government priorities - particularly if priorities are derived ex post, by looking at the appropriation of budgetary funds. On a priori grounds we cannot say whether this is "good" or "bad". Lundquist (1990:3) observed "that the housing market can be regarded as a system characterized by a perpetual process of adjusting households and dwellings to each other by the constant interaction between producer supply and consumer demand. The results of this process vary between two extremes: the principle of "housing for everyone according to their needs", and that of "housing on the basis of effective demand".

Not even a hard-core non-interventionist economist would subscribe to the view that effective demand is the only relevant principle governing the housing market. The opposite extreme, that of providing housing to everyone according to their needs, reads like a worn-out communist slogan. We are thus left in the middle ground, with a rationale for state intervention, but with no "objective" criterion on the amount of this intervention. This intervention is justified on purely theoretical considerations: housing is a merit good, the consumption of which produces positive external effects. It follows that - if the demand for housing rests only on effective private demand, the provision of housing would be less than socially desirable. How to reach this social optimum - whether through "rigging" demand or supply, remains uncertain: it can be ascertained only in the political process. 
tezo, da je prisilna akumulacija za stanovanjsko gradnjo $\vee 70$. in (delno) 80. letih pomenila čezmerno in neoptimalno rabo že tako skromnih sredstev. Stanovanjska gradnja je le eden od konkurentov, povpraševalcev, za omejenimi razpoložljivimi sredstvi. Ker so $v$ preteklosti pretežni del zasebnega varčevanja in pomemben del "prisilnega" družbenega varčevanja usmerjali v stanovanjsko gradnjo, bi lahko vsaj zagovarjali tezo, da takšna velika vlaganja $v$ stanovanjsko področje niso zaželjena. V premoženjskem portfelju slovenskih gospodinjstev namreč prevladuje potreba po stanovanju, to $p a z$ vidika sedanjih potreb $v$ gospodarskem razvoju ni posebno zaželjeno; celo nujno je, da premoženjsko bilanco bolj diverzificiramo in postopno vključimo tudi druge oblike lastnine (npr. lastniški "equity" kapital, državne obveznice itd). To seveda ne pomeni, da moramo stanovanjsko področje povsem zanemariti in ga "prepustiti" trgu oz. efektivnemu povpraševanju. Pomeni le, da bi z uvajanjem intervencionizma morali stremeti za tem, da bi se stanovanjsko področje čimbolj "odprlo" - predvsem s fiskalnimi ukrepi pa bi morali omogočiti večjo transparentnost in prehodnost, kar bi omogočilo bolj učinkovito rabo sedanjega fonda - predvsem z normalizacijo in povečevanjem ponudbe privatnega najemnega sektorja.

V zvezi s povečevanjem tega fonda pa bi z intervencionizmom morali spodbujati razvoj neprofitnega najemnega sektorja, ki je za dolgoročno uravnoteženje stanovanjske strukture nujen; velik delež lastniških stanovanj ni znamenje močnega privatnega sektorja temvečje bolj značilen za nerazviti kapitalizem.

km dr. Tine Stanovnik, Inštitut za ekonomska raziskovanja, Ljubljana
Namely, housing is not the only merit good competing for scarce resources - education and health care are also strong contestants. The provision - or rather state intervention in the provision of these merit goods depends on the broader type of welfare state. In other words, the provision of housing simply cannot be viewed in isolation from the provision of other merit goods and public goods.

Why is this point emphasized? While one could argue that housing construction in the 90 s is insufficient with regard to housing "needs", one could also argue, that the forced accumulation earmarked for housing construction, i.e. explicit and implicit subsidies for housing in the 70 s and up to the mid-80s represented a large and suboptimal use of scarce resources. Since in the past a major part of private savings (and large part of firm profits) were devoted to housing, the household balance sheet is dominated by housing. For the economic development of Slovenia a diversified household portfolio is quite necessary, particularly if one takes into account the rising capital markets, with such financial instruments available to the public (bonds, shares etc.) not available a decade ago.

Further increase in housing ownership can be more detrimental than helpful for the capital "cleepening" of Slovenia's economy.

The role of the state in such an environment is therefore not a heads-on support for housing construction, but more in providing the necessary measures to enhance the transparency of the housing market, including fiscal measures aimed at a better utilization of the existing housing stock and a sustained support for the development of the non-profit rental sector. One cannot overemphasize the fact that a large owner-occupied housing sector is not a sign of a strong private sector but more a sign of weak capitalism.

Dr. Tine Stanovnik, Institute for Economic Research, Ljubljana št. $28,29 / 1995$

\section{Literatura / References}

Lundquist, L.J. (1990). Rolling Stones for the Resurrection of Policy as the Focus of Comparative Housing Research, paper on the International Housing Research Conference Housing Debates - Urban Challenges, Paris.

Stanovnik, T. (1994). The Sale of the Social Housing Stock in Slovenia: What Happened and Why, Urban Studies, vol. 31 , no. 9, 1559-1570. 
no. $28,29 / 1995$

bo več velikih sosesk, sredstev za stanovanjsko gradnjo, ki bi jih zagotavljal sistem, manj bo črnih gradenj; prišlo pa bo do diverzifikacije stanovanjskega standarda, tipov zgradb in zazidalnih vzorcev. Zaenkrat bo prevladala miselnost "small is beautiful", predvsem pa bo gradbena tehnologija spet samo "dekla", ki služi arhitekturi.

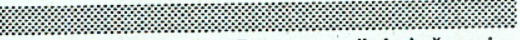
prof. dr. Vladimir Brezar, dipl. inž. arh., Fakulteta za arhitekturo, Ljubljana

\section{Opombe}

${ }^{1}$ Zanimiv primer je bilo demonstracijsko gradbišče Štepanjsko naselje (DGŠN): v objektih $\mathrm{P}+4$ so bili sami najemniki (večinoma $\mathrm{z}$ juga in podeželja), v stolpnicah $\mathrm{P}+12$ pa sami etažni lastniki, torej premožnejši srednji sloj, večinoma domači.

2 Primer Harvard: ko je Stirling utemeljeval svoj prizidek t.i. Fogg galerije, je dejal, da je pač "postavil še eno žival v živalski vrt...".

\section{Note}

1 The Štepanjsko Housing Estate Demonstration Project (ŠHEDP) presents an interesting example. The residents of the housing units in the four-storey buildings were all tenants (mostly migrants from the southern parts of the former Yugoslavia, and from rural areas, while apartments in the twelvestorey blocks were owner occupied by the more affluent middle class, mostly local inhabitants.

2 The Harvard example: In justifying his extension, to the Fogg Gallery, Stirling said that he "only put another animal in the zoo....".
The result is known. There is a need to point out the legal framework in particular. The town planning inspectorate operates and sanctions unauthorised housing construction but the building inspectorate does not exist. The measure of technical examination and the issuing of the operation permit is only rarely effected. Reconciliation of construction with the plan is not "secured", less still are the copyrights protected (which applies even to more legal multi-family construction).

It is therefore possible to state that the profession is not sufficiently in touch with real events in practice. May be the profession itself is to be blamed for this since it does not want to recognise what people really want and instead it is offering them its own view as to how they ought to live. The rare attempts at new forms of organised, compacted (single family) house building can hardly succeed, especially because they are organised and, as such, access to them is financially difficult. Apartments in blocks are also not more attractive just because they are "flexible" (since in effect nobody exploits this possibility), or because the facade is beautifully painted. Recently, however, it has been possible to observe that living near urban centres, in safe, well constructed and insulated buildings, with parking space in the basement ( $\mathrm{Zu}$ pančičeva Jama and Kotnikova housing estates) is becoming more attractive.

What is happening today and what is the future of housing construction in Slovenia?

We are presently at the stage of implementing the new housing act, although housing privatisation and the legalisation of unauthorised housing have been accomplished. Nonetheless, the most important implementation provisions (including the categorisation of housing units, the physical planning act, methodology for the legalisation of unauthorised housing, methodology for compacting the present dispersed building pattern) are yet to follow. With regard to planning documents, a number of new appro- aches is expected to be introduced over the whole country. At the same time, fresh investments are to be expected, particularly in the field of rented housing.

It will be extremely difficult to achieve all this in the new "capitalist circumstances", since the new (old) landowners are going to emerge with quite different interests with respect to the prices of building plots. These prices have suddenly increased, while there are only a few plots available. The price of land itself (rent) could put a halt to extensive urbanisation and allow for the rational use of plots in a more profitable way, in favour of quality instead of low price. A big plot is, therefore, appropriate for a "luxurious" mansion or high standard multi-family housing offering comfort which justifies the high economic rent, which also includes profit.

Housing construction will, as it has always been, continue to depend on politics. To put it another way, politics will have to continue dealing with the housing problem. It is difficult to say (judging from the prevailing situation) whether the profession will have any greater influence in the future. Notwithstanding the foreign models (e.g. Graz) and the knowledge that we have acquired at home in past decades (the Construction Centre of Slovenia, the Urban Planning Institute of the Republic of Slovenia and the Faculty of Architecture, Civil Engeneering and Geodesy), all of us will, once again, have to study the urbanism and construction that will be suitable to the demands of the market economy. It is very likely that there will be no more big neighbourhoods, no more public funds for housing construction and less unauthorised construction. This will lead to diversification in housing standards, building types and settlement patterns. For the time being, the notion "small is beautiful" will dominate, while building technology will once again be a "maid" at the service of architecture.

Dr. Vladimir Brezar, Professor and Dean of Faculty of Architecture, Ljubljana. 